\title{
Assessment of the attribute "Community Orientation" from the perspective of primary care adult users
}

\author{
Avaliação do atributo "Orientação Comunitária" na óptica do usuário adulto da atenção primária
}

Evaluación del atributo "Orientación Comunitaria" em la óptica del usuário adulto de la atención primaria

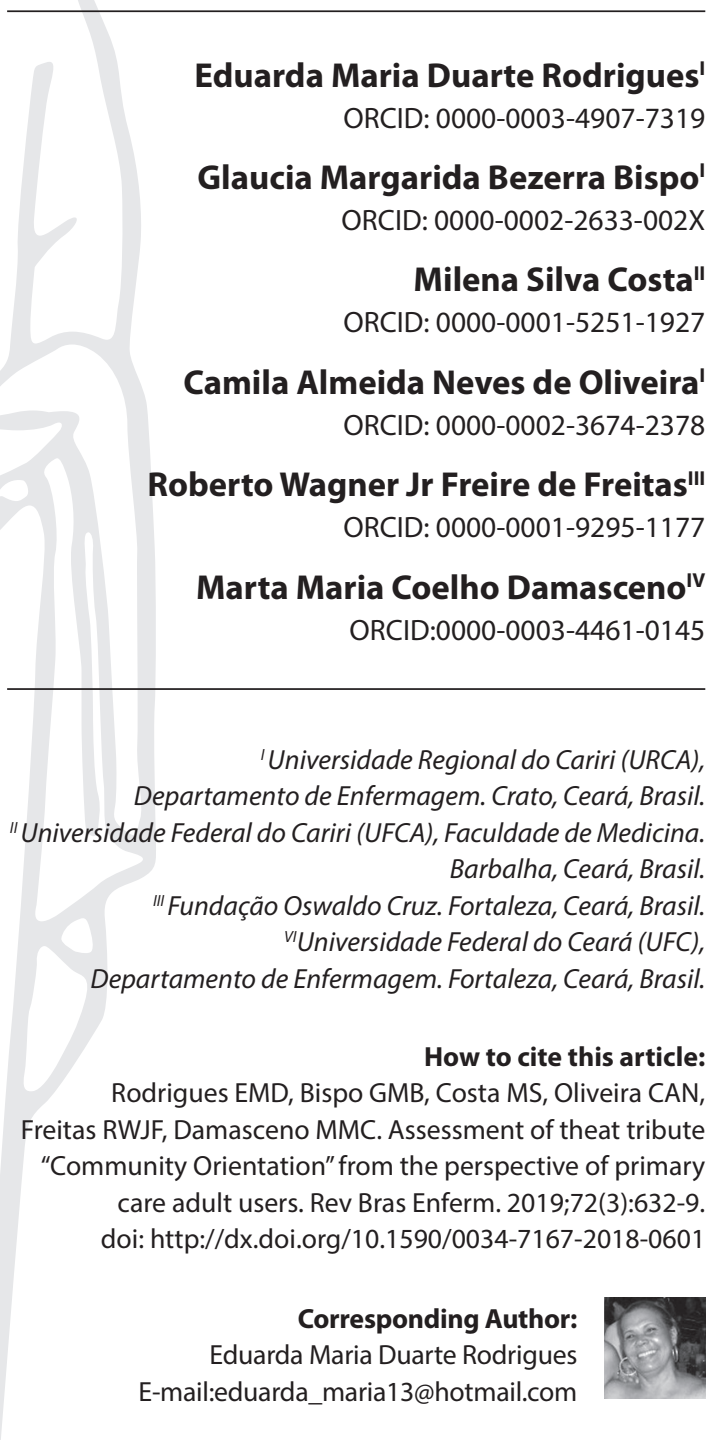

Submission: 07-24-2018 Approval: 03-02-2019

\begin{abstract}
Objective: To assess the presence and extension of the attribute "Community Orientation" of Primary Health Care from the perspective of health services adult users from the Municipality of Juazeiro do Norte-CE. Methods: Quantitative, cross-sectional and evaluative study, carried out in 14 Basic Health Units, from October 2016 to June 2017, using the Primary Care Assessment Tool. Results: The attribute assessment was negative, reaching expressive negative responses in the seven districts, with a mean score of $3.8( \pm 3.8)$. The Raw Score (RS) reached a mean of 6.6 and the Derived Score (DS) was assigned a score of 6.4 , below the cut-off point $\geq 6.60$. Conclusion: The low value of the DS represents that units are not providers of $\mathrm{PHC}$, suggesting fragility in the integration of services with the community and the need to promote greater discussion among agents, when designing measures of intervention and improvement of scores. Descriptors: Research on Health Services; Primary Health Care; Adult; Community Participation; Nursing.
\end{abstract}

\section{RESUMO}

Objetivo: Avaliar a presença e extensão do atributo "Orientação Comunitária" da Atenção Primária à Saúde, na perspectiva dos usuários adultos dos serviços de saúde do Município de Juazeiro do Norte-CE. Método: Estudo quantitativo, transversal e avaliativo, realizado em 14 Unidades Básicas de Saúde, no período de outubro de 2016 a junho de 2017, utilizando-se, para as entrevistas, o Primary Care Assessment Tool. Resultados: A avaliação do atributo foi negativa, alcançando expressivas respostas negativas nos sete distritos, com escore médio de 3,8 $( \pm 3,8)$. O Escore Essencial (EE) alcançou média de 6,6 e ao Escore Geral (EG) foi atribuída pontuação de 6,4, abaixo do ponto de corte $\geq 6,60$. Conclusão: $O$ baixo valor do $E G$ representa que as unidades não são provedoras de APS, sugerindo fragilidade na integração dos serviços com a comunidade e necessidade de promover maior discussão entre os agentes, ao traçar medidas de intervenção e melhoria dos escores.

Descritores: Pesquisa sobre Serviços de Saúde; Atenção Primária à Saúde; Adulto; Participação da Comunidade; Enfermagem.

\section{RESUMEN}

Objetivo: Evaluar la presencia y extensión del atributo "Orientación Comunitaria" de la Atención Primaria de Salud, bajo la perspectiva de los usuarios adultos de servicios de salud del Municipio brasileño de Juazeiro do Norte-CE. Método: Estudio cuantitativo, transversal y evaluativo, realizado en 14 unidades básicas de salud, en el período de octubre 2016 hasta junio 2017, utilizándose para las entrevistas el Primary Care Assessment Tool. Resultados: La evaluación del atributo fue negativa, alcanzando expresivas respuestas negativas en las siete regiones, con una puntuación media de $3,8( \pm 3,8)$. La Puntuación Esencial (Escore Essencial) alcanzó un promedio de 6,6 y a la Puntuación General (Escore Geral) se asignó una puntuación de 6,4, por debajo del punto de corte $\geq 6,60$. Conclusión: El bajo valor del EG representa que las unidades no son proveedores de APS, sugiriendo una fragilidad a la integración de los servicios con la comunidad y la necesidad de promocionar más discusiones entre los agentes, al trazar medidas de intervención y mejoría de las puntuaciones.

Descriptores: Investigación sobre los Servicios de Salud; Atención Primaria de Salud; Adulto; Participación de la Comunidad; Enfermería. 


\section{INTRODUCTION}

Primary Health Care (PHC), as a priority for the full care of public service users' needs, originates from the First International Conference on Primary Health Care held in Alma-Ata (1978), Kazakhstan. The recommendation of this Conference provided achievements relevant to health systems of several countries by declaring that health it is a fundamental human right, aiming at the preventive health of persons, families and assisted communities and distancing from clinical, individualistic, curative practice and excluding ${ }^{(1)}$.

Brazil sought to approximate the global proposal for PHC with the creation of the Brazilian Unified Health System (SUS Sistema Único de Saúde). The Family Health Strategy (FHS) has the essential tool for its expansion and implementation, seeking to overcome the curative model through a work process focused on principles, guidelines and fundamentals, by strengthening the quality of care, with greater resolvability on the health of individuals, families and communities, in addition to reducing cost-effectiveness ${ }^{(2)}$.

Within the challenges of the FHS, and for the system itself, listening to the users that seek Basic Health Units (BHU), which can be a way of expressing their real needs and the changes of the professional practices, towards the community participation in health decisions ${ }^{(3)}$.

From Starfield's ${ }^{(4)}$ conception, PHC represents the first level of a health system care. There are four essential attributes: first contact access, longitudinality, completeness; and coordination and three derivatives: family orientation, community orientation and cultural competence, principles that should provide theoretical and methodological support in the care of the total primary care dimension.

In order to evaluate the attribute "Community Orientation", health professionals need epidemiological and clinical skills to follow the actions developed in the programs, with the objective of regulating the programs and meeting the real health needs of population ${ }^{(5)}$. In this perspective, the SUS' Política Nacional de Atenção Básica (PNAB - National Policy of Primary Care) establishes that FHS actions are also developed within the community, prioritizing the care and democratic and participatory management of people, in order to favor their empowerment and autonomy ${ }^{(6)}$. One of the peculiarities of PHC is the health condition of a community, produced by environmental, behavioral aspects and its level of social connection. Improving the quality of PHC should focus on the physical and social environment in which people live and work $^{(7)}$.

The presence and extension of these attributes are evaluative precepts of PHC. Scientific evidence has pointed to the benefits of $\mathrm{PHC}^{(8,9)}$. However, there is a great heterogeneity in care, reflecting health outcomes. As a result, research evaluating the quality of $\mathrm{PHC}$ has been considered essential to identify how care has been offered by health providers ${ }^{(10,11)}$. Thus, it is important to include the practice of attributes, especially the "Community Orientation", in the work process of multiprofessional teams. Research that measured the presence and extent of community orientation in $\mathrm{PHC}$ confirmed negative scores, characterizing a contradiction to the postulates of PHC and PNAB ${ }^{(12,13)}$.
The specialized literature evidences a shortage of studies aimed at evaluating PHC services ${ }^{(14,15)}$. This shortage can be clarified by the insufficiency of appropriate tools ${ }^{(16)}$. Aiming to reduce this gap, a specific methodological study was carried out to evaluate $\mathrm{PHC}$, using validated tools in several countries, including Brazil ${ }^{(14,15)}$.

Likewise, when it comes to the Northeast Region, emphasis is given to the fact that there is a predominance of evaluations directed to the implementation of the FHS, treatment of diseases and injuries, as well as evaluation of the impact of the strategy on the quality of care provided ${ }^{(7)}$. It is also important to highlight that in Ceará State, even though it is a pioneer in primary care, there is still a certain lack of scientific production on the subject.

The evaluation of the attribute "Community Orientation" becomes relevant, since it favors listening to users' concerns and opinions so that, together, they can find the best solution ${ }^{(4,16)}$. Therefore, it is perceived that the elaboration of this relational strategy can improve the knowledge of health professionals of the BHU studied on the daily life experienced by users, family and community.

\section{OBJECTIVE}

This study aims to evaluate the presence and extension of the attribute "Community Orientation" of Primary Health Care from the perspective of health services adult users of the Municipality of Juazeiro do Norte-CE.

\section{METHOD}

\section{Ethical aspects}

Ethical recommendations contained in Resolution 466/2012 were granted in all phases of this study, receiving approval from the Ethics and Research Committee of the Universidade Regional do Cariri (URCA).

\section{Design, place of study and period}

A quantitative, descriptive, cross-sectional and evaluative study, carried out in 14 Basic Health Units (BHU), located in the urban and rural area of the city of Juazeiro do Norte, Ceará, Brazil, from 2015 to 2018 .

\section{Sample, criteria for inclusion and exclusion}

BHU users were selected for convenience as they were being treated or awaiting consultations by FHS health professionals. In this way, users belonging to the age group between 20 and 59 years old and enrolled in the FHS of the BHU surveyed were considered as inclusion criteria for at least one year, since they understood that they had better conditions to evaluate the care received.

As exclusion criterion, we determined: to present some limitation of communication and not to be in clinical and/or emotional conditions to participate in the research.

For the calculation of the sample size, $\mathrm{P}$ was set at $50 \%$, since this value implies maximum sample size. The significance level of 
$5 \%(a=0.05)$ was determined and a relative sample error of $8 \%$ (absolute sample error $=4 \%$ ) was established. These values applied in the formula for infinite populations $(\mathrm{N}=115,613)$ provided an " $\mathrm{n}$ " size sample of 600 users. $10 \%$ were added to prevent losses and/or withdrawals, thus reaching a sample of 660 participants. However, when performing a simple division for $14 \mathrm{BHU}, 47.14$ users were interviewed, and 48 users were rounded up to BHU, totaling 672 participants.

In the second phase, the sample was stratified and two BHUs were selected in the seven Health Districts to be applied the evaluation tool, which had the following criteria: membership of urban and rural areas, geographically located at extreme points of each other, aiming at capturing the differences in $\mathrm{PHC}$ attributes among the studied BHUs, 11 of the urban area and three of the rural area.

Finally, the sample consisted of 672 adult users, aged 20 to 59 years old, of both genders, treated at the $14 \mathrm{BHUs}$ selected and implanted for at least five years. Consideration was given to the longer contact time with this and thus greater knowledge about the source where the user is assisted when presenting old or new problems.

It is relevant to delineate that the choice of this municipality in the Cariri Region occurred because it represents the third population of the state of Ceará, after the capital Fortaleza and Caucaia, with a population estimated for 2015 in 266,022 thousand inhabitants, with a population concentration in the urban area of $96.07 \%$ (17).

Likewise, it is worth noting the option for the study aimed at adult users aged 20 to 59 years, due to the evidence indicated by the literature of the trend of progressive advancement of the economically active population in Brazil by $2030^{(12,18)}$, stands out; and the burden of Chronic Noncommunicable Diseases (CNCD) and its reflection on the quality of health of the adult population, in particular, which poses one of the major challenges for development in the $21^{\text {st }}$ century.

\section{Study protocol}

The interview script consisted of the application of two tools, the first one referring to the script of interviews containing eight sociodemographic variables of adult users, namely: gender, age, marital status, education, occupation, income, religion and residence zone. The second is the tool called PCATool BRAZIL, adults version ${ }^{(19)}$. For this study, six questions were used referring to the attribute "Community Orientation", composed of six items (J1 to J6), as described: J1. Does anyone of the "health service/ or doctor/nurse name "make home visits?; J2. Does your "health service/ or doctor/nurse name" know about the important health problems in your neighborhood?; J3. Does your"health service/ or doctor/nurse name" hear community opinions and ideas on how to improve health services?; J4. Do they do research with patients to see if services are satisfying (meeting) people's needs?; J5. Do they do research in the community to identify health issues that they should know about?; J6. Do they invite you and your family to participate in the Local Health Council (Management Council/User Council)? These questions were based on the concept described by Starfield ${ }^{(4)}$, who points out that actions in the community are
"[...] the recognition by health professionals during their work process of the health needs of the community, based on the epidemiological profile, popular participation and other data".

The responses to the six questions were structured, following the Likert Scale guidelines, where scores were assigned in the range of 1 to 4 for each attribute, namely: "Certainly" (value $=4$ ); "Probably yes" (value = 3); "Probably not" (value = 2); "Certainly not" $($ value $=1)$; and "I do not know or I do not remember" $(\text { value }=9)^{(20)}$.

Values obtained for each of the scores on the Likert Scale were converted to the scale from zero to ten, where the measures with values $\geq 6.60$ indicate the extent of each PHC attribute ${ }^{(19,20)}$. In this transformation, the guidelines of the manual were applied, using the following formula: (Score obtained - 1) X 10/3(21).

When the score is greater than or equal to 6.60 , it indicates the appropriate extension to each attribute and is evaluated as a strong orientation for PHC. If the value of the score is lower than 6.60, low orientation for PHC will be indicated. This value corresponds, on the scale of one to four, to score three ("probably yes"); Thus, values equal to or greater than 6.60 represent positive responses ${ }^{(21)}$.

Finally, the score of the attribute was calculated by summing the values of the six questions, dividing by its total $(\mathrm{J} 1+\mathrm{J} 2+\mathrm{J} 3+\mathrm{J} 4+\mathrm{J} 5+\mathrm{J} 6=\mathrm{J} 6 / 6)$, being considered as cut-off point $\geq$ 6.60. It is worth mentioning that data collection took place in the period from October 2016 to October 2017, in the dependencies of the selected BHUs, through individual interviews.

\section{Analysis of results, and statistics}

The answers were submitted to a double typing process, followed by storage using the Microsoft ${ }^{\circ}$ Excel program and processed by the Statistical Package for the Social Sciences (IBM SPSS), version 23.0. This program aimed at the correction of discordance between the data, with a descriptive analysis, such as the calculation of the statistical normality of Raw and Derived Scores of the PCATool. Scores were evaluated through the Shapiro-Wilk test, in order to define the appropriate tests to compare the scores in relation to other variables. In the absence of normality ( $p<0.001)$, the Mann-Whitney and Kruskal-Wallis tests were used to verify the association between the sociodemographic variables and Spearman's correlation test for comparisons with quantitative variables. The results were expressed in tables. For all inferential procedures, a significance level of $5 \%$.

\section{RESULTS}

Of the 672 participants, the mean age was 35.7 years ( \pm 11.2$)$, with a predominance of females with $508(75.6 \%)$, with complete elementary and middle school, 281 users (41.8\%) and only 42 completed higher education (6.3\%); 418 (62.5\%) are married/ common-law and most have income of up to one minimum wage, with 483 users (71.9\%). As for the occupation, 287 users work (43.2\%), with a high unemployment rate, with 354 (53.3\%), while 528 (78.6\%) live in urban areas.

In Table 1, it was demonstrated after the sum of each value of the six questions, according to formula: Score $=\mathrm{J} 1+\mathrm{J} 2+\mathrm{J} 3+\mathrm{J} 4+\mathrm{J} 5+\mathrm{J} 6 / 6$ that the attribute "Community Orientation" was evaluated 
negatively, with a mean score of 3.8, SD $( \pm 2.3),(p=0.303)$, below the cut-off point $(\geq 6.60)$, by users in the seven Health Districts, evidencing low orientation for $\mathrm{PHC}$, that is, users negatively evaluated the attribute.

In Table 2, of the six questions, only question (J1) related to the home visit was positively evaluated by 325 (71.3\%) participants. Responses to others ( $\mathrm{J} 2$ to $\mathrm{J} 6$ ) were negative, saying that the professional does not know the important health problems of the neighborhood, does not listen to the opinions and ideas of the community on how to improve health services, that satisfaction surveys are not conducted of users regarding the service and who are not invited to participate in the Local Health Council/ Users Council.

Table 1 - Distribution of the minimum, maximum, mean, standard deviation and orientation of PHC's "Community Orientation" attribute from adult users, Juazeiro do Norte-CE, 2017

\begin{tabular}{lc}
\hline Scores Values & Attribute “Community Orientation” \\
\hline Minimum & 0.0 \\
Maximum & 10.0 \\
Mean & 3.8 \\
Standard Deviation & \pm 2.3 \\
Orientation degree for PHC & Low \\
\hline
\end{tabular}

Table 3 shows that, in most Health Districts, there was a significant association (0.001). That is, showing difference, except for district IV, which did not reach significance $(p=0.303)$.

\section{DISCUSSION}

The evaluation of PHC attributes, from the perspective of adults, is low in Brazil compared to professionals and children ${ }^{(22,23)}$. It is noteworthy that this study of the attribute "Community Orientation", from the perspective of adults treated at public health services, is a pioneer in the municipality of this research, with only one dedicated to the child version ${ }^{(24)}$.

As for the analysis of the attribute "Community Orientation" by users, a negative evaluation was observed in all $14 \mathrm{BHUs}$ of the seven Health Districts. Thus, suggesting another indicator of fragility to the integration of services with the community, in the Municipality. Similar results were found in other national and international studies ${ }^{(25,26,27) \text {. }}$

On the one hand, the minor role of users in the $\mathrm{PHC}$ evaluation process may be due to researchers' restrictions on their ability to perform a health assessment ${ }^{(11)}$; on the other hand, the fact that the health system itself historically prioritizes women and children, not prioritizing these adult users ${ }^{(28)}$.

Table 2 - Frequency distribution of BHU adult users' answers to the items that make up the attribute "Community Orientation". Juazeiro do Norte - CE, 2017

\begin{tabular}{|c|c|c|c|c|c|}
\hline Community Orientation(J) & Certainly not & Probably not & $\begin{array}{l}\text { Probably yes } \\
\text { n (\%) }\end{array}$ & Certainly & $\begin{array}{l}\text { Attribute's } \\
\text { score }\end{array}$ \\
\hline $\begin{array}{l}\text { J1- Does any of the "health service/ or doctor/nurse name" make home } \\
\text { visits? }\end{array}$ & $32(7.0)$ & $44(9.6)$ & $55(12.1)$ & $325(71.3)$ & 3.8 \\
\hline $\begin{array}{l}\text { J2- Does your" health service/ or doctor/nurse name" know about the } \\
\text { important health problems in your neighborhood? }\end{array}$ & $194(42.5)$ & $91(20.0)$ & $108(23.7)$ & $63(13.8)$ & \\
\hline $\begin{array}{l}\text { J3 - Does your "health service/ or doctor/nurse name"hear community opinions } \\
\text { and ideas on how to improve health services? }\end{array}$ & $182(39.8)$ & $76(16.7)$ & $143(31.4)$ & $55(12.1)$ & \\
\hline $\begin{array}{l}\text { J4- Do they do research with patients to see if services are satisfying } \\
\text { (meeting) people's needs? }\end{array}$ & $247(54.2)$ & $42(9.2)$ & $132(28.9)$ & $35(7.7)$ & \\
\hline $\begin{array}{l}\text { J5- Do they do research in the community to identify health issues that } \\
\text { they should know about? }\end{array}$ & $262(57.5)$ & $85(18.6)$ & $88(19.3)$ & $21(4.6)$ & \\
\hline J6-Do they invite you and your family to participate in the Local Health Council? & $308(67.5)$ & $56(12.3)$ & $79(17.3)$ & $13(2.9)$ & \\
\hline
\end{tabular}

Table 3 - Bivariate analysis of PHC's "Community Orientation" Health District from the perspective of BHU adult users, Juazeiro do Norte-CE, 2017

\begin{tabular}{lcccc}
\hline \multirow{2}{*}{ Health Districts (HD) } & \multicolumn{4}{c}{ Attribute “Community Orientation” } \\
& Mean & SD & P value & Score \\
\hline District I & 3,3 & $\pm 1,6$ & & \\
District II & 4,4 & $\pm 3,0$ & & \\
District III & 3,5 & $\pm 2,0$ & & \\
District IV & 3,7 & $\pm 2,1$ & $<0,303$ & 3,8 \\
District V & 4,2 & $\pm 2,8$ & & \\
District VI & 3,4 & $\pm 2,3$ & \\
District VII & 4,4 & $\pm 2,5$ & \\
\hline Mann-Whitney's Test. & & &
\end{tabular}

Mann-Whitney's Test.
Also, it is highlighted that the literature has been pointing out that PHC evaluation in Brazil occurs more frequently in the Midwest, Southeast and South Regions ${ }^{(22,29)}$. In the Northeast, research is still scarce, evidencing a lack of knowledge on the subject $^{(30,31)}$. In this sense, in the Northeast Region, there are evaluative studies of PHC in Fortaleza ${ }^{(31,32)}$.

Regarding the sociodemographic profile of users, it is worth noting that in Brazil, there is a greater frequency of women in public health services and they admit that they abandon other routine activities due to illness ${ }^{(30)}$; and adults and seniors in this study are identical to other national and international surveys ${ }^{(21,33,34)}$.

It is noteworthy that the majority of the participants had on average 35 years, are married, with complete elementary and middle school. People with higher education (above 13 years of 
age) are perceived to have higher health perceptions compared to those with lower levels of schooling ( 1 to 8 years). While the population with lower educational level is less critical when evaluating the services received, thus expressing better satisfaction $^{(12,33)}$. Along the same lines, follow international studies.

Income up to a minimum wage was corroborated by previous studies $^{(35)}$. The demand for the health system increases at the extremes of the ages, that is, from $0-14$ in $12 \%$ and $23 \%$ in excess of 60 years. It also increases with the increase in family income per person ${ }^{(36)}$. Concerning the employment situation, $53.3 \%$ were unemployed $(n=354)$ and only $43.2 \%$ worked $(n=287)$.

Given the findings, it was possible to observe that the attribute "Community Orientation" obtained a negative evaluation with a score of $3.8( \pm 2.3)$ in all 14 BHUs and in all seven Health Districts (Table 3). This result resembles those found in recent studies ${ }^{(2)}$. This fact compromises the empowerment of autonomy and the city, established in Law 8142/90(37).

These findings may contribute to the discussion of the need for the development of public policies in the municipality studied and perhaps at the national level. Policies that encourage community participation, promote health and assist managers in reflecting on their decisions, favoring community empowerment, broadening the right to citizenship, and improving the quality of life.

The attribute "Community Orientation" allows FHS health professionals to know the physical, social, cultural, epidemiological and behavioral space of people living in the community, who resonate about the health situation of users. One of the forms of approximation and knowledge of the reality experienced by the families that constitute the focus of the FHS work process is the home visit $(\mathrm{HV})^{(2)}$. When asked if any professional performed HV, 48.4\% stated "certainly yes". It is up to these to use this moment to establish links with families, to develop actions of health promotion and prevention of diseases ${ }^{(38)}$. A study carried out in Mato Grosso State showed that it is not a unique characteristic of the nurse practitioner, noting that physicians also do not perform it, repeating the focus on the "biologicist" model directed at the person.

The low score, with a mean of $3.8( \pm 2.3)$ may indicate that there was influence of the negative evaluations of the attribute "Integrity", in both components, and "Access First Contact - Accessibility". This negative evaluation is an indication that $\mathrm{BHU}$ deficiency may be occurring by disregarding the physical, social, economic, cultural and family environment in its planning ${ }^{(4)}$.

Likewise, the fact that $57.5 \%(n=262)$ of users stated that they were not aware of the research on the level of satisfaction of the needs of the people (J5), is similar to the findings of previous studies. $42.5 \%$ (194) of the interviewees asserted (J2) that "certainly" professionals are unaware of community health problems. It is inferred that users' distance from research is due to the deficiency of their elaboration or because they are carried out during home visits, without the proper explanation of the purpose of the study ${ }^{(26)}$. In this sense, a study carried out in São Luiz ${ }^{(9)}$, aiming at this theme, reveals a large number of "I do not know" answers and negative evaluation, proving the community's lack of knowledge about the actions developed by the FHS or its elementary participation in democratic forums, such as the Municipal Health Council.
When asked if the professionals listened to their opinions and ideas during the consultations (J3), 41.6\% ( $n=271)$ affirmed "certainly not" and "probably not" and $49.5 \%=322$ ) stated that "certainly yes".

Another score lower than the cutoff point $(\geq 6.60)$ points to the fact that only $2.9 \%(n=13)$ of users (J6) admitted that they were invited to attend the meetings of the Municipal Health Council. SUS, established to be implemented by the FHS, is based on the comprehensiveness of health care and community participation in the solutions of problems ${ }^{(26)}$. This empowerment promotes continuous access to information by users and the community to learning opportunities for health issues. As well as greater involvement and co-responsibility of these in the fight for greater financial investments for $\mathrm{PHC}$, in addition to the ethical professional commitment of health in effecting this attribute as a way to contribute to the promotion of citizenship to population.

In this context, negative results of the study demonstrate the imperative of a change in the work process of Family Health Teams, aiming to promote participation of population in the formulation of proposals and interventions that can face social, cultural and economic constraints, primary care or in deliberations of the Health Council. So the executive's performance can harmonize with knowledge, interests and needs of population.

Under these circumstances PNPS, Ordinance 2,446 / 2014, adopts the expanded concept of health, aiming to achieve health promotion, quality of life, equity, reduction of vulnerability and health risk. PNPS seeks to broaden the autonomy and coresponsibility of population in the comprehensive health care and, consequently, achieve the reduction of unjust and avoidable historical inequalities, through dialogue between technical, scientific and popular knowledge ${ }^{(39)}$.

Therefore, the attribute "Community Orientation" requires community participation in the FHS work process, by expanding spaces of debate between health professionals and community, in order to allow better access to the community health needs, and favor longitudinal bond and social control.

In such a way, professionals, in partnership with managers and community, must create mechanisms and conditions to recognize and analyze the local situation and recommend changes in the FHS work process, when diagnosed problems.

\section{Study limits}

Among the study limits, cross-sections are highlighted, which only examine the exposure-disease relationship, pointing out the characteristics of variables at a given moment. Also, the fact that the evaluation research of PHC has been carried out only from users' perspective, may occur natural acceptance of the low quality of the care received from the provider, interpreting it as a favor, rather than a right, leaving explicit the current social representation in society that everything public and free is of poor quality.

\section{Contributions to the fields of Nursing and Public Health}

The study points to enormous contributions of nursing professionals in the exercise of actions directed at different population groups that make up public policies and programs that promote 
health promotion and preventive care. Therefore, the results of this research point out the importance of the professional nurse in the assessment of the attribute "Community Orientation", thus allowing greater recognition and visibility by the community of their preventive work and health promotion. It also contributes to municipal planning and the execution of care.

\section{CONCLUSION}

The attribute "Community Orientation" was evaluated according to users of the researched BHU, which was much lower than the one recommended by the PCATool ( $\geq 6.60)$, showing a low presence and extension of this attribute, hampering the guarantee of comprehensive and universal care, and of quality to population of the communities attached to each BHU. Thus, challenges remain to be faced by management and health professionals, such as the reorganization of $\mathrm{PHC}$, in order to guarantee comprehensive and universal care for adult users.

It is recommended to carry out further evaluation studies in which other agents, such as professionals, managers and community agents are included. They should aim to facilitate a process of comparison of ways of thinking and acting on the health care of adults and, therefore, identifying the main needs of this population and suggest proposals for joint interventions more appropriate to the reality experienced by the user.

Lastly, the findings in this research investigate the precision of greater discussion in universities, scientific events and the community about the quality of health of adults and so that the professional is able to offer comprehensive care to them at all levels of health.

\section{REFERENCES}

1. Ministério da Saúde (BR), Gabinete do Ministro. Portaria n².488, de 21 de outubro de 2011. Aprova a Política Nacional de Atenção Básica, estabelecendo a revisão de diretrizes e normas para a organização da Atenção Básica, para a Estratégia Saúde da Família (ESF) e o Programa de Agentes Comunitários de Saúde (PACS) [Internet]. Diário Oficial da União: República Federativa do Brasil; 2011 [cited 2019 Mar 12]. Nov 10, Seção 1: [about 20 screens]. Available from: http://bvsms.saude.gov.br/bvs/saudelegis/gm/2011/prt2488_21_10_2011.html

2. Araújo JP, Viera CS, Toso BRGO, Collet N, Nassar PO. Avaliação dos atributos de orientação familiar e comunitária na saúde da criança. Acta Paul Enferm [Internet]. 2014;27(5):440-446. Available from: http://www.scielo.br/pdf/ape/v27n5/pt_1982-0194-ape-027-005-0440.pdf

3. da Silva SA, Fracolli LA. Evaluating child care in the family health strategy. Rev Bras Enferm [Internet]. 2016 [cited 2019 Mar 12];69(1):47-53. Available from: doi:10.1590/0034-7167.2016690107i

4. Starfield B. Atenção primária: equilíbrio entre necessidades de saúde, serviços e tecnologia [Internet]. Brasília: UNESCO, Ministério da Saúde; 2002. 726p. Available from: https://www.nescon.medicina.ufmg.br/biblioteca/imagem/0253.pdf

5. Oliveira MAC, Pereira IC. [Primary health care essential attributes and the family health strategy]. Rev Bras Enferm [Internet]. 2013 [cited 2019 Mar 12];66(esp):158-64. Available from: http://dx.doi.org/10.1590/S0034-71672013000700020 Portuguese.

6. Harzheim E, Starfield B, Rajmil L, Álvarez-Dardet C, Stein AT. [Internal consistency and reliability of primary care assessment tool (PCAToolBrasil) for child health services]. Cad Saúde Pública [Internet]. 2006 [cited 2019 Mar 12];22(8):1649-59. Available from: http://dx.doi. org/10.1590/S0102-311X2006000800013 Portuguese.

7. Fracolli LA, Muramatsu MJ, Gomes MFP, Nabão FRZ. [Evaluation of the primary health care attributes in a municipality located in the countryside of São Paulo state - Brazil]. Mundo Saúde [Internet]. 2015 [cited 2019 Mar 12];39(1):54-61. Available from: http://dx.doi. org/10.15343/0104-7809.201539015461 Portuguese.

8. Fracolli LA, Gomes MFP, Nabão FRZ, Santos MS, Cappellini VK, Almeida ACC. Primary health care assessment tools: a literature review and metasynthesis. Ciênc Saúde Colet [Internet] 2014 [cited 2019 Mar 12];19(12):4851-4860. Available from: http://dx.doi. org/10.1590/1413-812320141912.00572014

9. Alencar MN, Coimbra LC, Morais APP, Silva AAM, Pinheiro SRA, Queiroz RCS. [Evaluation of the family focus and community orientation in the family health strategy]. Ciênc Saúde Colet [Internet]. 2014 [cited 2019 Mar 12];19(2):353-64. Available from: doi:10.1590/141381232014192.08522012 Portuguese.

10. Donabedian A. The quality of care. how can it be assessed? JAMA [Internet]. 1988 [cited 2018 Aug 28];260(12):1743-8. Available from: http:// dx.doi.org/10.1001/jama.1988.03410120089033

11. Araújo LUA, Gama ZAS, Nascimento FLA, Oliveira HFV, Azevedo WM, Almeida Jr HJB. [Evaluation of the quality of primary health care from the perspective of the elderly]. Ciênc Saúde Colet [Internet]. 2014 [cited 2019 Mar 12];19(8):3521-32. Available from: http://dx.doi. org/10.1590/1413-81232014198.21862013 Portuguese.

12. Paula WKAS, Samico IC, Caminha MFC, Batista Filho M, Figueirôa JN. [Community guidance and family focus: evaluation of users and professionals of the family health strategy]. Cad Saúde Colet [Internet] 2017 [cited 2019 Mar 12];25(2):242-48. Available from: http://dx.doi. org/10.1590/1414-462X201700020113 Portuguese.

13. Gomes MPF, Fracolli LA. Evaluation of the Family health strategy from the professionals' perspective. Rev Bras Promoç Saúde [Internet] 2018 [cited 2018 Aug 28];31(3):1-13 Available from: http://dx.doi.org/10.5020/18061230.2018.7108

14. Marques AS, Freitas DA, Leão CDA, Oliveira SKM, Pereira MM, Caldeira AP. [Primary Care and maternal and child health: perceptions of caregivers in a rural 'quilombola' community]. Ciênc Saúde Colet [Internet]. 2014 [cited 2019 Mar 12];19(2):365-71. Available from: http:// 
dx.doi.org/10.1590/1413-81232014192.02992013 Portuguese.

15. Malta DC, Santos MAS, Stopa SR, Vieira JEB, Melo EA, Reis AAC. Family health strategy coverage in brazil, according to the national health survey, 2013. Ciênc Saude Colet [Internet]. 2016 [cited 2019 Mar 12];21(2):327-38. Available from: http://dx.doi. org/10.1590/1413-81232015212.23602015

16. Carvalho ALB, Souza MF, Shimizu HE, Senra IMVB, Oliveira KC. [SUS management and monitoring and evaluation practices: possibilities and challenges for building a strategic agenda]. Ciênc Saude Colet [Internet]. 2012 [cited 2019 Mar 12];17(4):901-11. Available from: http:// dx.doi.org/10.1590/S1413-81232012000400012 Portuguese.

17. IBGE: Instituto Brasileiro de Geografia e Estatística [Internet]. Dados populacionais. Brasília (DF): IBGE; 2015 [cited 2019 Mar 12]. Available from: https://ww2.ibge.gov.br/home/estatistica/populacao/estimativa2015/estimativa_dou.shtm

18. Marques SRL, Escarce AG, Lemos SMA. Health literacy and self-rated health in adults primary care patients. CoDAS [Internet]. 2018 [cited 2019 Mar 12];30(2):e20170127. Available from: http://dx.doi.org/10.1590/2317-1782/20182017127

19. Harzheim E, Oliveira MMC, Agostinho MR, Hauser L, Stein AT, Gonçalves MR, et al. [Validation of the primary care assessment tool: PCAToolBrazil for adults]. Rev Bras Med Fam Com [Internet]. 2013 [cited 2019 Mar 12];8(29):274-84. Available from: https://doi.org/10.5712/ rbmfc8(29)829 Portuguese.

20. Ministério da Saúde (BR), Secretaria da Atenção à Saúde, Departamento de Atenção Básica. Manual do instrumento de avaliação da atenção primária à saúde: primary care assessment tool PCATool - Brasil. Brasília: Ministério da Saúde, 2010 [cited 2019 Mar 12]. 80p. Available from: http://bvsms.saude.gov.br/bvs/publicacoes/manual_avaliacao_pcatool_brasil.pdf

21. Pina JC, Moraes AS, Furtado MCC, Mello DF. Presence and extent of the primary healthcare attributes among children hospitalized for pneumonia. Rev Lat Am Enf [Internet] 2015 [cited 2019 Mar 12];23(3):512-9. Available from: http://dx.doi.org/10.1590/0104-1169.0502.2582

22. Ferreira VD et al. Assessment of primary healthcare attributes in one municipality of minas gerais state. Esc Anna Nery [Internet]. 2016 [cited 2019 Mar 12];20(4):e20160104. Available from: http://dx.doi.org/10.5935/1414-8145.20160104

23. Santos NCCB et al. [Presence and extent of primary care characteristic sunder different models for children's healthcare]. Cad Saúde Pública [Internet]. 2018 [cited 2018 Aug 29];34(1):e00014216. Available from: http://dx.doi.org/10.1590/0102-311X00014216 Portuguese.

24. Macedo JCB. Avaliação da Atenção à Saúde da Criança no contexto da Estratégia Saúde da Família, em um município do estado do Ceará [Thesis in the Internet]. Ribeirão Preto (SP): Escola de Enfermagem de Ribeirão Preto, 2016 [cited 2019 Mar 12]. Available from: file:///D:/ Users/Windows7/Downloads/JANAINACARVALHOBRAZMACEDO\%20(2).pdf

25. Araújo RL, Mendonça AVM, Sousa MF. [Perception of users and health professionals in the federal district: the attributes of primary care]. Saúde Debate [Internet]. 2015 [cited 2019 Mar 12];39(105):387-99. Available from: http://dx.doi.org/10.1590/0103-110420151050002007 Portuguese.

26. Daschevi JM, Tacla MTGM, Alves BA, Toso BRGO, Collet, N. [Evaluation of the principles of family counseling and community primary care child health]. Semina Ciênc Biol Saúde [Internet]. 2015 [cited 2019 Mar 12];36(1):31-38. Available from: http://dx.doi.org/10.5433/16790367.201v36n1p31 Portuguese.

27. Prates ML, Machado JC, Silva LS, Avelar PS, Prates LL, Mendonça ET. Performance of primary health care according to PCATool instrument: a systematic review. Ciênc Saude Colet [Internet]. 2017 [cited 2019 Mar 12];22(6):1881-93. Available from: http://dx.doi. org/10.1590/1413-81232017226.14282016

28. Vieira RP, Gomes SHP, Machado MFAS, Bezerra IMP, Machado CA. Participation of adolescents in the Family Health Strategy from the theoretical-methodological structure of an enabler to participation. Rev Lat Am Enferm [Internet] 2014 [cited 2019 Mar 12];22(2):309-16 Available from: http://dx.doi.org/10.1590/0104-1169.3182.2417

29. Silva AS, Baitello TC, Fracolli LA. Primary health care evaluation: the view of clients and professionals about the family health strategy. Rev Lat Am Enferm [Internet]. 2015 [cited 2019 Mar 12];23(5):979-87. Available from: http://dx.doi.org/10.1590/0104-1169.0489.2639

30. Lima EFA, Sousa Al, Primo CC, Leite FMC, Lima RCD, Maciel ELN. An assessment of primary care attributes from the perspective of female healthcare users. Rev Lat Am Enferm [Internet]. 2015 [cited 2019 Mar 12];23(3):553-9. Available from: http://dx.doi. org/10.1590/0104-1169.0496.2587

31. Silva AN, Silva SA, Silva ARV, Araújo TME, Rebouças CBA, Nogueira LT. Primary care assessment from a male population perspective. Rev Bras Enferm [Internet]. 2018 [cited 2019 Mar 12];71(2):236-243. Available from: http://dx.doi.org/10.1590/0034-7167-2016-0651

32. Rolim LB. Avaliação dos atributos da Atenção Primária à Saúde de Fortaleza-CE: estudo através do PCATool-Brasil, versão profissionais. [Dissertation the Internet]. Rio de Janeiro: Rede Nordeste de Formação em Saúde da Família, Mestrado Profissional em Saúde da Família; 2016 [cited 2019 Mar 12]. Available from: https://renasf.fiocruz.br/avalia\%C3\%A7\%C3\%A3o-dos-atributos-da-aten\%C3\%A7\%C3\%A3oprim\%C3\%A1ria-\%C3\%A0-sa\%C3\%BAde-de-fortaleza-ce-estudo-atrav\%C3\%A9s-do-pcatool-brasil

33. Harmuch C, Baratieri T. [Assessment of the longitudinatily in primary health care from the users standpoint]. Varia Sci Ciênc Saúde [Internet]. 2017 [cited 2019 Mar 12];3(1). Available from: http://e-revista.unioeste.br/index.php/variasaude/article/view/16263 Portuguese.

34. Gontijo TL, Duarte AGS, Guimarães EAA, Silva J. [Evaluation of primary care: the point of view of users]. Saúde Debate [Internet]. 2017 [cited 2019 Mar 12];41(114):741-52. Available from: http://dx.doi.org/10.1590/0103-1104201711406 Portuguese.

35. Vaz EMC, Magalhães RKBPM, Toso BRGO, Reichert APS, Collet N. Longitudinality in childcare provided through Family Health Strategy. Rev Gaúcha Enferm [Internet]. 2015 [cited 2019 Mar 12];36(4):49-54. Available from: http://dx.doi.org/10.1590/1983-1447.2015.04.51862 
36. Ruiz ENF, Gerhardt TE. [Public policies in rural areas: visibility and social participation as perspectives of supportive citizenship and health]. Physis [Internet]. 2012 [cited 2019 Mar 12];22(3):1191-1209. Available from: http://dx.doi.org/10.1590/ S0103-73312012000300018 Portuguese.

37. Presidência da República (BR). Casa Civil, Subchefia para Assuntos Jurídicos. Lei no 8.142, de 28 de dezembro de 1990. Dispõe sobre a participação da comunidade na gestão do Sistema Único de Saúde (SUS) e sobre as transferências intergovernamentais de recursos financeiros na área da saúde e dá outras providências [Internet]. 1990. Diário Oficial da União: República Federativa do Brasil; 1990. Dec 28, Seção 1: [about 4 screens]. Available from: http://www.planalto.gov.br/ccivil_03/leis/L8142.htm

38. Andrade RD, Santos JS, Maia MAC, Silva MAI, Veríssimo MLOR, Mello DF. Home visit: care technology used by nurses to advocate for child's health. Texto Contexto Enferm [Internet]. 2015 [cited 2019 Mar 12];24(4):1130-8. Available from: http://dx.doi. org/10.1590/0104-0707201500000120015

39. Ministério da Saúde (BR), Gabinete do Ministério. Portaria no 2.446/GM de 11 de novembro de 2014. Redefine a Política Nacional de Promoção da Saúde (PNPS) [Internet]. Diário Oficial da União: República Federativa do Brasil; 2014 [cited 2019 Mar 12]. Mar 30, Seção 1: [about 12 screens]. Available from: http://bvsms.saude.gov.br/bvs/saudelegis/gm/2014/prt2446_11_11_2014.html 